\title{
Dyeing of Wool Fabric Using Natural Dye and Natural Mordant Extracts
}

\author{
Taame Berhanu Teklemedhin* \\ Department of Textile Engineering, Dire Dawa University, Ethiopia
}

*Corresponding author: Taame Berhanu Teklemedhin, Lecturer and Researcher in Textile Chemistry Department of Textile Engineering, Dire Dawa Institute of Technology, Dire Dawa University, P.O.BOX:1362, Dire Dawa, Ethiopia.

submission: 悳 September 10, 2018; Published: 眥 November 05, 2018

\begin{abstract}
Dyeing of textiles with natural dye was started in the early stage by the traditional dyers. In this century, a global awareness is already in place favoring the use of natural resources for protecting the environment and earth from pollution and ecological imbalances. In this study fully, environmental friendly dyeing of wool fabric was investigated using natural dye and natural mordant extracted from Cassia singueana plant and mango bark respectively. Wool fabric was dyed with Cassia singueana extract using different combinations of dyeing temperature, time, pH and concentration of extracted dye solution. Color strength, CIE L*a*b* and fastness properties (washing, rubbing and light), were investigated. The fastness property results of all dyed wool fabric samples with Cassia singueana plant extract were in the range of Good to excellent.
\end{abstract}

Keywords: Natural dye; Natural mordant; Cassia sigueana; Mango bark; Environmental friendly

\section{Introduction}

A growing interest in natural dyes in textile application is mainly due to its environmental friendly, an alternative economical, harmony with nature and biodegradability property. In many of the world's developing countries, however, natural dyes can offer not only a rich and varied source of dyestuff, but also the possibility of an income through sustainable harvest [1]. In fact, natural dyes are dyes and pigments obtained from animal or herbal sources, acquired by using no or minimal chemical treatments.

Presently there is an excessive use of synthetic dyes, estimated at around 10,000,000 tons per annum, the production and application of which release vast amounts of waste and unfixed colorants, causing serious health hazards and disturbing the ecobalance of nature [1]. Having this in mind, many scientists focused on extraction and standardization of natural dye to be used in textile coloration as an alternative of synthetic dyes. Natural dyes can be classified according to dyeing properties, chemical structure, origin (animal, herbal, mineral), hue or application area food industry, pharmaceutical industry. Cassia singueana plant was used as natural colorant in Ethiopia for dyeing of silk and tanned leather materials. The extract of this plant was also used in northern Nigeria for the treatment of anti- microbial and acute malaria attack $[2,3]$. It has also composition of Phenols, Saponins, Tannins and anthraquinones and those chemical compositions of tannins and anthraquinones indicates that it can be used as coloring material $[2,4]$. Natural dyes were extracted from different plants and applied to tanned leather in the presence of mordants and without mordant under identical conditions to find out whether the extracted dye shows affinity to tanned leather in the absence of mordant [5]. Win [6] was also extract natural dye from mango bark and applied on Protein fibers with temperature, time and MLR of $50-80{ }^{\circ} \mathrm{C}, 60 \mathrm{~min}$ and 1:25 respectively. The dyed material gives good color fastness property and attractive color shade. Natural dye was extracted from Odinawodier plan bark and applied on wool fabric with different temperature such as 40,60 and $80^{\circ} \mathrm{C}$ for 1 hour which is done by Saravanan [7]. It has been noted that, the K/S value/color strength was good at $80^{\circ} \mathrm{C}$.

Natural dye was extracted from Cassia singueana plant was successfully used in dyeing of silk fabric in the presence of Aloe Vera juice as natural mordant [8]. Tanned leather materials were dyed using extracted natural dye from this plant in the presence of natural mordants extracted from Aloe Vera and mango bark [9]. The possibility of using extract of bark of mango tree (Mangifera indica) as a mordant to dye cotton fabric with natural dye (bitter leaves) has been investigated by Wangatia [10]. This work was mainly focused on dyeing of wool fabric using natural dye and natural mordant extracted from Cassia singueana plant and mango bark respectively.

\section{Materials}

\section{Materials and chemicals}

Cassia singueana plant and mango bark were collected from Northern Ethiopia (Tigray) and Bahir Dar university (Poly campus) respectively. Pretreated wool fabric was obtained from market. Acetic acid $\left(\mathrm{CH}_{2} \mathrm{COOH}\right)$ and copper sulphate were used to 
control the $\mathrm{pH}$ of the dye bath and used as synthetic mordant for comparison respectively.

\section{Equipment and testing devices}

Main equipment and testing devices used throughout this work were; mechanical grinder was used to grind and change the mango bark and cassia singueana bark in to powder. Eco-infrared dyeing machine (IR-Dyeing) was used to extract the natural dye and mordant. Oven dryer was used to dry the dyed fabric. pH meter used to check $\mathrm{pH}$ of the dye solution. Digital electronic balance was used to measure weight of materials and chemicals. Perkin Elmer UV/VIS Spectrometer was used for measuring absorption/concentration of the extracted dye and mordant. COLOREYE 3100-was used for measuring reflectance, K/S and CIE L*a*b* and Fastness (Wash fastness, Light Fastness and Rubbing fastness) testing devices. All those Equipment and Testing Devices were obtained from Bahir Dar University-EiTEX.

\section{Methods}

\section{Dye extraction and optimization}

Aqueous extraction method was employed to extract natural dye from bark Cassia singueana plant bark using Eco-infrared dyeing machine. Plant parts were collected and washed thoroughly with water to remove soil and dust particles. The washed plant materials were dried, grinded and sieved with 0.5 particle size to obtain the fine powder [11]. The powder was immersed in distilled water using different combinations of bark concentrations of $(20 \mathrm{~g} / \mathrm{l}, 40 \mathrm{~g} / \mathrm{l}$ and $60 \mathrm{~g} / \mathrm{l})$ for 24 hours. The solution was subjected to temperatures of $\left(45,75\right.$ and $\left.95{ }^{\circ} \mathrm{C}\right)$ and time $(30 \mathrm{~min}, 45 \mathrm{~min}$ and $60 \mathrm{~min}$ ) respectively. The dye solution was filtered and its absorption was tested using UV-visible spectroscopy (Model lambda25). The temperature, concentration and time at which attain maximum absorption was taken as an optimum condition for extraction of natural dye from Cassia singueana.

\section{Mordanting methods and mordant extraction from mango bark}

The bark of mango tree was washed with water to remove the impurities and dried at room temperature. Once the bark gets dried, it was ground in to fine powder using mechanical grinding machine and sieved with 0.5 particle size as shown in Figure 1. According to Wangatia [10] Mango bark was extracted at a concentration of $15 \mathrm{~g} / 200 \mathrm{ml}$ and temperature of $90^{\circ} \mathrm{C}$ for $1 \mathrm{hr}$. Therefore, by taking this literature as reference similar mordant extraction method was followed and the filtered solution was used as it is as a mordant in natural dyeing of wool fabric. Wool fabric samples were treated with the extracted natural mordant using three different mordanting techniques (i.e. Pre mordanting, Post Mordant and simultaneous mordanting).

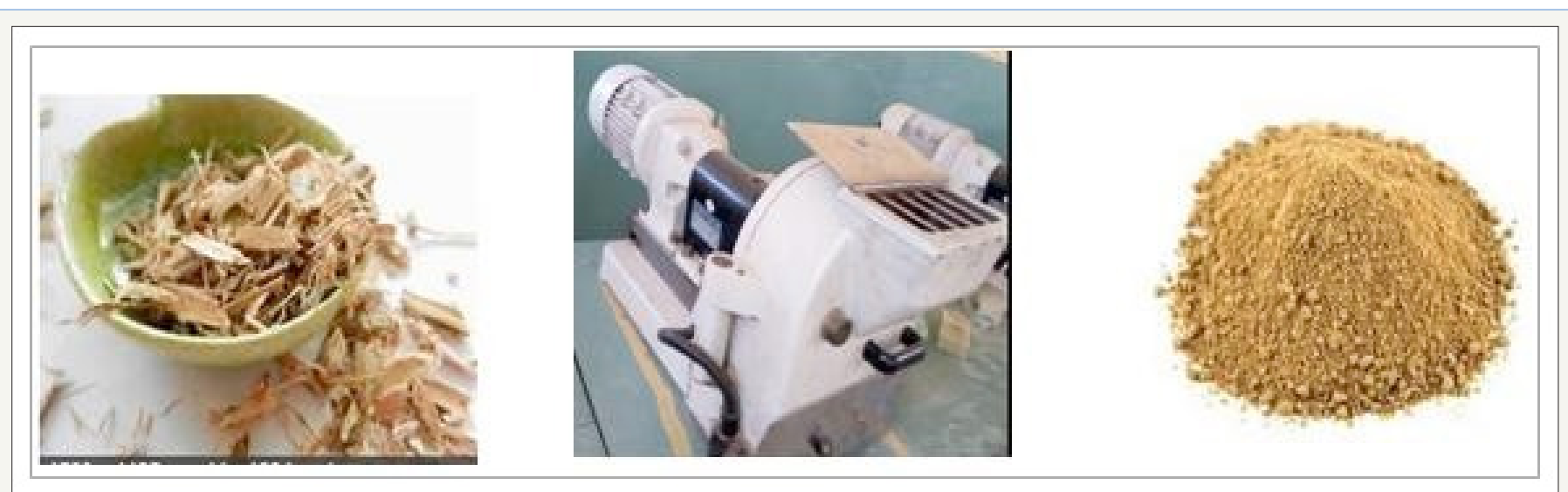

Figure 1: Extraction of natural mordant from mango bark.

\section{Dyeing Procedure}

Dyeing of wool fabric was performed with $60 \mathrm{~g} / \mathrm{l}$ of aqueous dye extracts from bark of cassia singuana plant and natural mordant at different combinations of randomly selected dyeing temperature of $25,40,55$ and $70{ }^{\circ} \mathrm{C}$, time of $20,30,45$ and $60 \mathrm{~min}$ and $\mathrm{pH}$ of $5.5,5,4.5,4$ and 3.5 as shown in Table 1 . The temperature, $\mathrm{pH}$ and time at which the dyed wool fabric attained highest K/S value or Color strength were selected as optimum dyeing condition. Four experiments were selected through random selection method and conducted under each dyeing and mordanting methods. The weight of each specimen which was dyed with the extracted dye was 50 grams.

\section{Evaluation of dyed wool fabric sample}

Color fastness (Wash fastness, rubbing fastness light fastness) properties of the dyed wool fabric samples were determined under the optimized conditions according to ISO 105-CO3, ISO 105-X 12 methods and ISO 105B02 method respectively.

\section{Results and Discussion}

\section{Optimization of natural dye extraction from Cassia singueana plant}

Natural dye solution was extracted from the bark of Cassia singueana plant at different bark powder concentration, temperature and time. The absorption (A) of resultant solution was 
determined using UV-Visible spectroscopy (Lambda 25). Maximum dye solution absorption was obtained at concentration of $60 \mathrm{~g} / \mathrm{l}$, temperature of $95^{\circ} \mathrm{C}$ and time of $60 \mathrm{~min}$ were selected as optimum condition.

\section{Performance test results of dyed wool fabric samples}

Color strength $(\mathrm{k} / \mathrm{s})$ value, reflectance $(\%)$ and CIE $\mathrm{L}^{*} \mathrm{a}^{*} \mathbf{b}^{*}$ value: Color developed and color strength on dyed wool fabric samples was evaluated in terms of their CIEL*a*b* coordinates and $\mathrm{K} / \mathrm{S}$ values. The $\mathrm{L}^{*}$ (lightness/ darkens), $\mathrm{a}^{*}$ (redness/greenness), $\mathrm{b}^{*}$ (yellowness/blueness) value of dyed wool fabric samples obtained from all dyeing and mordanting methods was lied in dark gray to light gray, red and yellow direction respectively as shown in Table 2.

It was observed that, the color strength $(\mathrm{K} / \mathrm{S})$ value was good at $\mathrm{pH}$ of 4 . Dye-ability of wool fabric with the extracted natural dye was evaluated by dying different samples of wool in the presence of mango bark and copper mordants. Maximum K/S (color strength) was got from dyed fabric samples at maximum temperature of 70 ${ }^{\circ} \mathrm{C}$ and time of $60 \mathrm{~min}$ and $\mathrm{pH} 4$ as shown in Table $1 \& 2$. This is due to the increments of kinetic energy leads to increase diffusion of dye molecules inside the wool fabric at high temperature and increase diffusion rate of dye molecules in to the wool structure at long dyeing time.

Table 1: Different combinations of parameters used to dye wool fabric with the extracted natural dye.

\begin{tabular}{|c|c|c|c|c|}
\hline Dyeing conditions & pH & Temperature $\left({ }^{\circ} \mathrm{C}\right)$ & Time & Output samplecode \\
\hline \multirow{4}{*}{ Dyeing without mordant } & 5.5 & 25 & 20 & D1 \\
\hline & 5 & 40 & 30 & D2 \\
\hline & 4.5 & 55 & 45 & D3 \\
\hline & 4 & 70 & 60 & D4 \\
\hline \multirow{4}{*}{ Pre-Mordanting with mango bark } & 5.5 & 25 & 20 & Pr1 \\
\hline & 5 & 40 & 30 & $\operatorname{Pr} 2$ \\
\hline & 4.5 & 55 & 45 & $\operatorname{Pr} 3$ \\
\hline & 4 & 70 & 60 & $\operatorname{Pr} 4$ \\
\hline \multirow{4}{*}{ Post-Mordanting with mango bark } & 5.5 & 25 & 20 & Po1 \\
\hline & 5 & 40 & 30 & Po2 \\
\hline & 4.5 & 55 & 45 & Po3 \\
\hline & 4 & 70 & 60 & Po4 \\
\hline \multirow{4}{*}{ Simultaneous mordanting with mango bark } & 5.5 & 25 & 20 & S1 \\
\hline & 5 & 40 & 30 & S2 \\
\hline & 4.5 & 55 & 45 & S3 \\
\hline & 4 & 70 & 60 & S4 \\
\hline Pre-Mordanting with copper sulphate & 3.5 & 60 & 60 & DCPrm \\
\hline Post-Mordanting with copper sulphate & 3.5 & 60 & 60 & DCPom \\
\hline $\begin{array}{c}\text { Simultaneous mordanting with copper } \\
\text { sulphate }\end{array}$ & 3.5 & 60 & 60 & SMC \\
\hline
\end{tabular}

Key: $\mathrm{D}=$ dyeing without mordant, $\mathrm{Pr}=$ pre mordanted, $\mathrm{Po}=$ post mordanted, $\mathrm{S}=$ simultaneously mordanted, $\mathrm{DCPrm}=$ Dyed and pre mordanted with copper sulphate, DCPom $=$ Dyed and post mordanted with copper sulphate, $\mathrm{SMC}=$ simultaneously mordanting with copper sulphate. 
Table 2: Color strength $(\mathrm{K} / \mathrm{S})$ value, reflectance $(\%)$ and CIEL*a* $\mathrm{b}^{*}$ values of dyed wool fabric samples with the extracted dye and using different mordants at $10^{\circ}$ observer.

\begin{tabular}{|c|c|c|c|c|c|c|}
\hline \multirow{2}{*}{ Method } & \multirow{2}{*}{$\begin{array}{l}\text { Sample } \\
\text { Code }\end{array}$} & \multirow{2}{*}{ Reflectance (\%) at $400 \mathrm{~nm}$} & \multirow[b]{2}{*}{$\begin{array}{c}\mathrm{K} / \mathrm{S} \text { at } 400 \\
\mathrm{~nm}\end{array}$} & \multicolumn{3}{|c|}{ CIE L*a*b* system } \\
\hline & & & & $\mathbf{L}^{*}$ & $a^{*}$ & $\mathbf{b}^{*}$ \\
\hline \multirow{4}{*}{ Directly dyed without mordant } & D1 & 6 & 3.6 & 50.5 & 22.2 & 23 \\
\hline & D2 & 6.4 & 2.9 & 54.23 & 16.8 & 22.5 \\
\hline & D3 & 6.1 & 3.4 & 52.01 & 18.25 & 21.48 \\
\hline & D4 & 4.3 & 4.2 & 45.2 & 27.4 & 20.09 \\
\hline & Pr1 & 8.07 & 2.04 & 57.32 & 15.6 & 22.1 \\
\hline \multirow{3}{*}{ PRM with mango bark } & Pr2 & 7.25 & 2.52 & 53.14 & 19.60 & 23.07 \\
\hline & Pr3 & 6.48 & 2.25 & 49.07 & 17.5 & 28.05 \\
\hline & Pr4 & 4.50 & 4.90 & 45.32 & 25.02 & 26.26 \\
\hline \multirow{4}{*}{ POM with mango bark } & Po1 & 7.26 & 2.14 & 57.74 & 13.82 & 20.18 \\
\hline & Po2 & 6.48 & 4.15 & 52.58 & 19.66 & 23.29 \\
\hline & Po3 & 6.25 & 4.27 & 49.68 & 24.06 & 27.07 \\
\hline & Po4 & 5.48 & 5.12 & 48.74 & 17.03 & 25.90 \\
\hline \multirow{4}{*}{ SM with mango bark } & S1 & 6.85 & 4.43 & 49.96 & 15.40 & 21.86 \\
\hline & S2 & 5.68 & 5.61 & 47.72 & 16.58 & 23.18 \\
\hline & S3 & 5.26 & 5.65 & 50.92 & 16.81 & 26.20 \\
\hline & S4 & 5.15 & 5.83 & 44.26 & 17.92 & 24.72 \\
\hline PRM with copper sulphate & DCPrm & 3.65 & 8.82 & 36.91 & 10.99 & 16.79 \\
\hline POM with copper sulphate & DCPom & 3.94 & 8.22 & 39.00 & 16.54 & 21.27 \\
\hline SM with copper sulphate & SMC & 3.33 & 10.42 & 32.77 & 16.57 & 15.96 \\
\hline
\end{tabular}

Fastness test results of dyed wool fabric samples: The fair (3-3/4) test results. Samples pretreated with mango bark performance of Washing fastness, rubbing fastness and light extract and directly dyed samples showed very good to excellent fastness of the dyed wool fabric specimens were presented in Table rubbing and washing fastness, and good to very good light fastness 3. In most of the dyed fabric samples, the performance of fastness property was recorded. In general, natural dye extracted from bark property was rated within the range of 3-5. For the light fastness of Cassia singueana plant could be used for commercial purpose test results, all dyed wool fabric samples showed good to excellent in dyeing of wool fabric in the acceptable color fastness range of except some samples which were directly dyed without mordant international standards as shown in Table 3. and samples which were post mordanted with mango bark showed

Table 3: Color fastness properties test result of dyed wool samples.

\begin{tabular}{|c|c|c|c|c|c|c|c|c|}
\hline \multirow[t]{2}{*}{$\begin{array}{l}\text { Type } \\
\text { Mordant }\end{array}$} & \multirow[t]{2}{*}{$\begin{array}{ll}\mathbf{0} & \mathbf{f}\end{array}$} & \multirow[t]{2}{*}{$\begin{array}{l}\text { Method of Mor- } \\
\text { danting }\end{array}$} & \multirow[t]{2}{*}{$\begin{array}{l}\text { S a m p l e } \\
\text { Code }\end{array}$} & \multicolumn{2}{|c|}{$\begin{array}{l}\text { Rubbing Fastness } \\
\text { (ISO 105- } \\
\text { X 12) }\end{array}$} & \multirow{2}{*}{$\begin{array}{l}\text { Light Fastness } \\
\text { (ISO 105B02) } \\
24 \mathrm{hr}\end{array}$} & \multicolumn{2}{|c|}{$\begin{array}{l}\text { Wash Fastness } \\
\text { (ISO Methods of ISO 105-CO3 }\end{array}$} \\
\hline & & & & Dry & Wet & & Acidic & Basic \\
\hline \multirow{4}{*}{ Nil } & & \multirow{4}{*}{ Dyed without mordant } & D1 & 4 & $3 / 4$ & 4 & $3 / 4$ & $3 / 4$ \\
\hline & & & D2 & $3 / 4$ & 3 & 4 & 3 & 3 \\
\hline & & & D3 & 3 & 4 & 5 & 4 & $4 / 5$ \\
\hline & & & D4 & 4 & 4 & $4-5$ & 3 & 5 \\
\hline
\end{tabular}




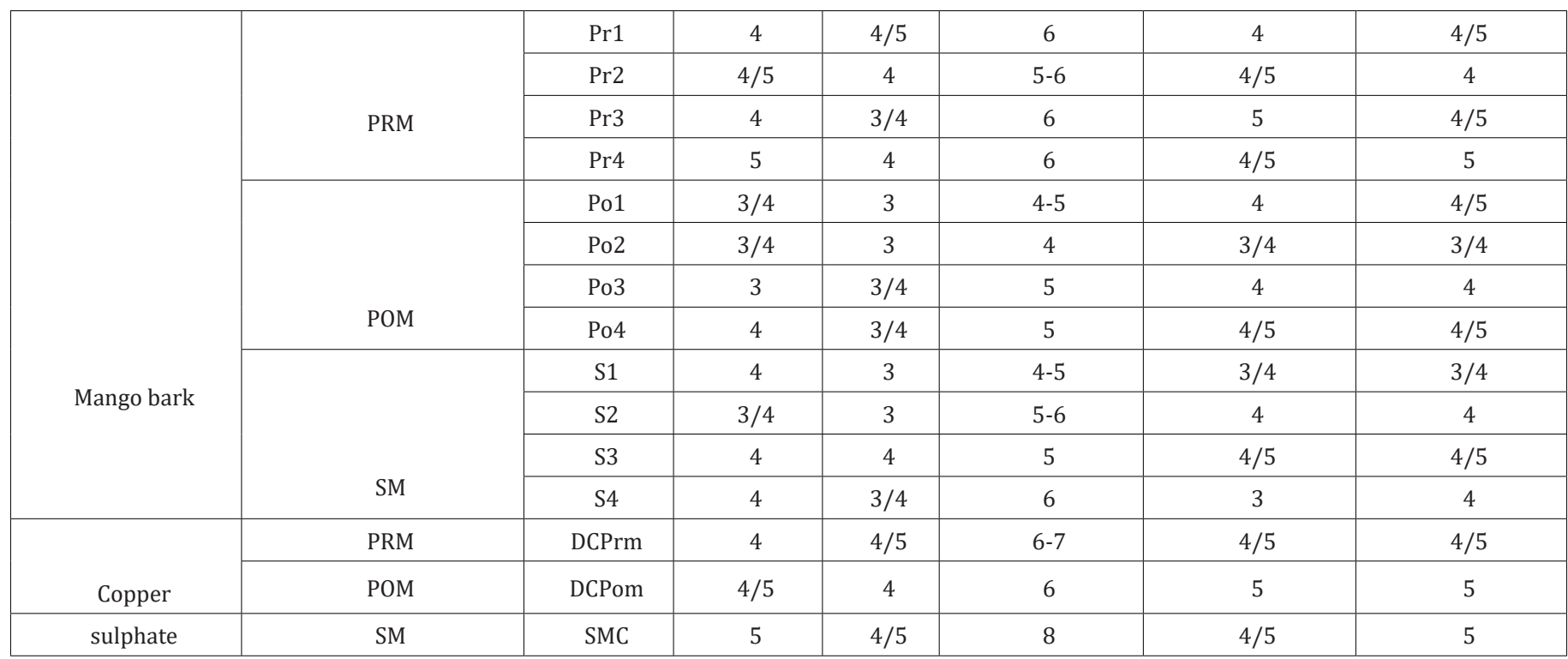

\section{Conclusion}

Wool fabric was successfully dyed with natural dye extracted from Cassia singueana plant in the presence of natural mordant of mango bark extract. It was found from the study that the bark of Cassi singuana plant extracted dye can be successfully used for dyeing of wool in the presence of natural and synthetic mordants. With regards to color fastness, test samples exhibited excellent fastness to washing (except pre and post mordanting); excellent fastness to rubbing and light fastness (except some samples simultaneous and post mordanting-with mango bark). The extracted dye is eco-friendly and biodegradable, having no health hazard effects and eco-label. The Cassia singueana plant used as natural colorant and mango bark used as natural mordant are easily available in Ethiopia which makes the raw material cheep.

\section{References}

1. Belemkar S, Ramachandran M (2015) Recent trends in Indian textile industry-Exploring novel natural dye products and resources. International Journal on Textile Engineering and Processes 1(3): 33-41.

2. Endo M, Naoki H (1980) Antimicrobial and antispasmodic tetrahydroanthracenes from Cassia singueana. Tetrahedron 36(17): 2449-2452.

3. Adzu B, Abbah J (2003) Studies on the use of Cassia singueana in malaria ethnopharmacy. Journal Ethnopharmacol 88(2-3): 261-267.
4. Mutasa S, Khan M (1990) 7-Methylphyscion and Cassiamin A from the root bark of Cassia singueana. Planta med 56(2): 244-245.

5. Kulkarni S, Gokhale A (2011) Cotton dyeing with natural dye extracted from pomegranate (Punica granatum) Peel. Universal Journal of Environmental Research \& Technology 1(2): 135-139.

6. Win ZM, Swe MM (2008) Purification of the natural dyestuff extracted from Mango bark for the application on protein fibers. World Acad Sci Eng Technol 22: 536-540.

7. Saravanan GC, Mariajancyrani J, Kiruthikajothi K (2014) Eco-friendly dyeing of wool fabric with a natural dye extracted from barks of Edina wodier. Pelagia Research Library 5(1): 28-33.

8. Teklemedhin TB, Gopalakrishnan LH (2018) Environmental friendly dyeing of silk fabric with natural dye extracted from Cassia singueana plant. J Textile Sci Eng S3: 001. doi: 10.4172/2165-8064.S3-001.

9. Berhanu T, Ratnapandian S (2017) Extraction and optimization of natural dye from hambo (Cassia singueana) plant used for coloration of tanned leather materials. Advances in Materials Science and Engineering.

10. Wangatia LM, Tadesse K (2015) Mango bark mordant for dyeing cotton with natural dye: fully eco-friendly natural dyeing. International Journal of Textile Science 4(2): 36-41.

11. Sangeetha K, Bhuvaneshwari M (2015) Dyeing of silk fabric using lemon leaves. International Journal of Innovative Research in Science, Engineering and Technology 4(6): 4692-4697.
Creative Commons Attribution 4.0

International License

For possible submissions Click Here

Submit Article

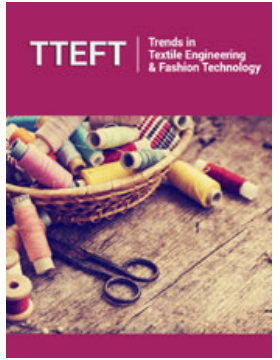

Trends in Textile Engineering \& Fashion Technology

\section{Benefits of Publishing with us}

- High-level peer review and editorial services

- Freely accessible online immediately upon publication

- Authors retain the copyright to their work

- Licensing it under a Creative Commons license

- Visibility through different online platforms 